\title{
Ectopic Inferior Orbital Meningioma
}

\author{
${ }^{1}$ Pankaj Gupta, ${ }^{2}$ Abiraj Kumar, ${ }^{3}$ Bruttendu Moharana, ${ }^{4}$ Kim Vaiphei, ${ }^{5}$ Chirag Ahuja
}

\begin{abstract}
Aim: To present a unique case of ectopic orbital meningioma presenting in anteroinferior part of orbit.

Introduction: Primary orbital meningiomas arise from the optic nerve sheath and constitute 10 to $30 \%$ of orbital meningiomas. Secondary orbital meningiomas represent 70 to $90 \%$ of orbital meningiomas and are the direct extension of intracranial meningiomas into the orbit. Rarely, ectopic rests of arachnoid cells give rise to meningiomas separate from optic nerve sheath. Ectopic orbit meningioma is a rare tumor arising from ectopic arachnoidal tissue. The present case report describes an elderly patient with ectopic orbital meningioma in anteroinferior quadrant.
\end{abstract}

Case report: A 70-year-old female patient presented with slowly growing mass in the inferior part of right orbit. This lesion was firm in consistency and not fixed to skin or bone. Computed tomography scan showed a homogeneous mass lesion in anteroinferior part of right orbit without any bony changes. The orbital mass was excised. Anatomic-pathologic evaluation of the excised specimen revealed a benign meningioma of a meningotheliomatous type.

Conclusion: Ectopic orbital meningioma may present in elderly patients in anteroinferior orbit.

Clinical significance: An ectopic orbital meningioma should be considered in differential diagnosis of firm orbital mass presenting in anteroinferior orbit.

Keywords: Anteroinferior, Ectopic, Extraconal, Meningioma, Orbit.

How to cite this article: Gupta P, Kumar A, Moharana B, Vaiphei K, Ahuja C. Ectopic Inferior Orbital Meningioma. Clin Rhinol An Int J 2017;10(1):32-35.

Source of support: Nil

Conflict of interest: None

\section{INTRODUCTION}

Meningiomas of the orbit are uncommon and account for $4 \%$ of intraorbital tumors. They can be divided into two

${ }^{1}$ Additional Professor, ${ }^{2,3}$ Senior Resident, ${ }^{4}$ Professor, ${ }^{5}$ Associate Professor

${ }^{1-3}$ Department of Ophthalmology, Postgraduate Institute of Medical Education \& Research, Chandigarh, India

${ }^{4}$ Department of Histopathology, Postgraduate Institute of Medical Education \& Research, Chandigarh, India

${ }^{5}$ Department of Radiodiagnosis, Postgraduate Institute of Medical Education \& Research, Chandigarh, India

Corresponding Author: Pankaj Gupta, Additional Professor Department of Ophthalmology, Postgraduate Institute of Medical Education \& Research, Chandigarh, India, e-mail: drpankajkgupta@gmail.com categories: Primary and secondary orbital meningiomas. Primary orbital meningiomas arise from optic nerve sheath and constitute 10 to $30 \%$ of all orbital meningiomas. Secondary orbital meningiomas represent 70 to $90 \%$ of orbital meningiomas and are direct extension of intracranial meningiomas into the orbit. Rarely ectopic rests of arachnoid cells give rise to meningiomas separate from optic nerve sheath. Ectopic orbit meningioma is a rare tumor arising from ectopic arachnoidal tissue. The present case report describes an elderly patient with ectopic anteroinferior orbital meningioma.

\section{CASE REPORT}

A 70-year-old female patient presented with a gradually, painless progressive swelling in inferior part of orbit for past 1 year. The past and medical histories were unremarkable. Visual acuity was 20/20 in both eyes. Palpation of the right orbit showed presence of firm, smooth surfaced, mass in inferior nasal quadrant that was not adherent to skin or bone. The globe was pushed superiorly and laterally (Fig. 1A). Computed tomography scan of orbits showed a homogeneous hyperdense mass located in anteroinferior part of right orbit (Fig. 1B). A right anterior inferior orbitotomy was done and a welldefined circumscribed, firm, grayish-brown mass measuring $20 \times 20 \times 10 \mathrm{~mm}$ in size was excised. Microscopy revealed cells displaying a meningothelial morphology and a syncytial growth pattern, with nuclei showing little monomorphic to minimally pleomorphic oval- to spindleshaped cells with vesicular nuclei and nuclear grooving with prominent nucleoli, with scanty to moderate amount of cytoplasm with indistinct boundary between adjacent cells (Fig. 2A). Immunohistochemistry with epithelial membrane antigen and vimentin positivity confirmed the meningothelial nature of the cells (Fig. 2B). Other epithelial markers including cytokeratin, S-100 protein, and smooth muscle actin stains were negative. The Ki 67 immunostaining was performed to assess the proliferation rate of the lesion with a labeling index of $7 \%$. After 1 year of follow-up, the patient was disease free.

\section{DISCUSSION}

Orbital meningiomas are primarily divided into two types: (1) Primary optic nerve sheath meningioma, which originate from the arachnoid around the optic nerve, (2) secondary orbital meningiomas occur due to orbital 


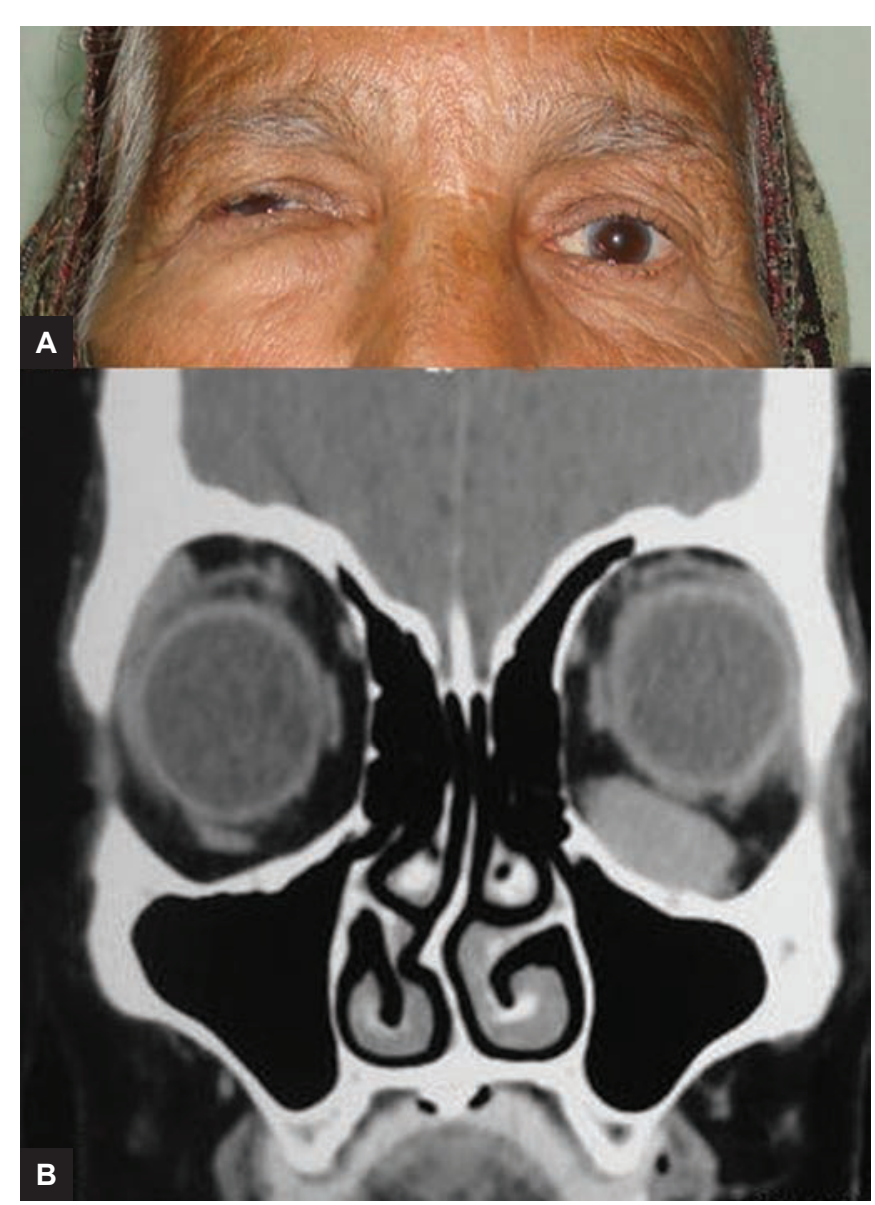

Figs 1A and B: (A) Presence of proptosis and upward globe displacement; and (B) CT orbits showing localized homogeneous mass in inferior orbit of same density as of muscle with displacement of globe superolateral and normal bony orbits

invasion of intracranial meningioma. A third group of orbital meningioma known as ectopic meningioma occurs away from the optic nerve without any demonstrable connection with the intracranial meninges. Farah et $\mathrm{al}^{1}$ in 1999 had reported a case of ectopic orbital meningioma and reviewed previously reported cases. They could find only five published cases of orbital ectopic meningioma that had sufficient clinical, radiologic, and histopathological evidence to support this diagnosis. This condition is probably an underreported entity as previously there was no consensus on existence of ectopic orbital meningioma. Also, some cases might have been thought of as an extension of intracranial meningioma. Here, we describe 14 cases $^{1-10}$ of ectopic orbital meningioma previously reported that have sufficient clinical, radiologic, and histopathological evidence to support the diagnosis and the case that we reported here. Table 1 summarizes patient demographics, tumor location, treatment, follow-up, complications, tumor connection to optic nerve, and histopathologic classification in 15 cases with ectopic orbital meningioma. Mean age was 30.4 years (7-70 years). It occurred throughout all

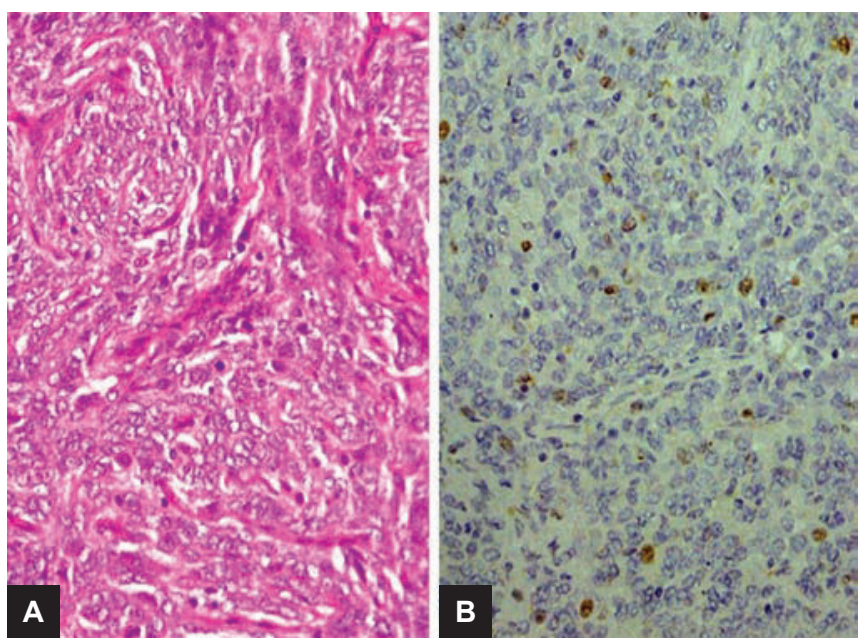

Figs 2A and B: (A) Tumor showing mildly pleomorphic oval- to spindle-shaped cells arranged in whorls with vesicular nuclei and moderate amount of eosinophilic cytoplasm in distinct boundary (hematoxylin and eosin, 250×); and (B) Nuclear positivity for Ki-67 in immunohistochemistry staining (peroxidase anti-peroxidase, $250 \times)$

age groups with a male predominance (ten males, five females). Five out of 15 (33\%) patients have involvement of medial orbital space. Superomedial space was involved in 3 out of $15(20 \%)$ cases; superior, lateral and inferomedial spaces were involved in 2 out of $15(13 \%)$ cases each; superolateral space was involved in 1 out of 15 (7\%) cases. Ectopic orbital meningiomas have a well-circumscribed appearance in most of the cases. However, in four cases, it presented as diffusely growing mass. ${ }^{2,7,9}$ Calcification was present in three cases. ${ }^{1,2,6}$

Hyperosteosis/sclerosis of adjacent bone was present in three cases. Calcification in the lesion ${ }^{1,2,6}$ was found in three cases, and hyperosteosis/sclerosis ${ }^{7}$ of adjacent bone was seen in two cases. Ectopic orbital meningioma usually appears as a well-circumscribed lesion, but it can also be ill-defined. ${ }^{2,7}$ Connection of the mass to optic nerve was absent in 10 cases and was not specifically mentioned in 5 cases, whereas connection to the periorbita was present in four cases and absent or not mentioned in the rest. The pathogenesis of ectopic orbital meningioma is not clear. There are various theories put forward about the origin of ectopic orbital meningiomas. Tan and Lim $^{11}$ proposed three possible ways: (1) From occasional arachnoid "nests" in the orbit; (2) from the optic nerve sheath with loss of connection before discovery; and (3) from smaller nerves endowed with arachnoid cells. These lesions may originate from regressed orbital meningoceles with leftover arachnoid tissue trapped within orbital soft tissues. Another hypothesis is that congenitally dislocated nests of meningoepithelial cells located within the orbit ${ }^{6}$ give rise to the lesion. It may be associated with trauma to the orbit, which dislodges meningeal tissues within the orbit, which serve as a 
Table 1: Demographics and clinical details of patients with ectopic orbital meningioma

\begin{tabular}{|c|c|c|c|c|c|c|c|c|c|}
\hline $\begin{array}{l}\text { SI. } \\
\text { no. }\end{array}$ & Author & $\begin{array}{l}\text { Age/ } \\
\text { Sex }\end{array}$ & Location & $\begin{array}{l}\text { Secondary } \\
\text { treatment }\end{array}$ & $\begin{array}{l}\text { Follow-up } \\
\text { (months) }\end{array}$ & Complications & $\begin{array}{l}\text { Connection } \\
\text { to optic } \\
\text { nerve }\end{array}$ & $\begin{array}{l}\text { Connection } \\
\text { to periorbital }\end{array}$ & $\begin{array}{l}\text { Histological } \\
\text { variant }\end{array}$ \\
\hline 1 & Johnson et al ${ }^{2}$ & 10/M & Medial & Craniotomy & 12 & Ptosis & Absent & - & Meningothelial \\
\hline 2 & ${\text { Johnson et } \mathrm{al}^{2}}^{2}$ & $7 / \mathrm{M}$ & Medial & $\begin{array}{l}\text { External } \\
\text { ethmoidectomy }\end{array}$ & 4 & None & Absent & - & Meningothelial \\
\hline 3 & Spraul et $\mathrm{al}^{3}$ & $30 / \mathrm{M}$ & Medial & None & 18 & None & - & - & Fibroblastic \\
\hline 4 & Arai et al ${ }^{4}$ & $27 / F$ & Superomedial & None & 1 & None & Absent & Absent & Fibroblastic \\
\hline 5 & Farah et $\mathrm{al}^{1}$ & $53 / \mathrm{M}$ & Medial & None & 42 & None & Absent & Present & Meningothelial \\
\hline 6 & Yokoyama et $\mathrm{al}^{5}$ & $7 / \mathrm{M}$ & Inferomedial & None & 0 & Optic atrophy & Absent & Absent & Meningothelial \\
\hline 7 & Decock et $\mathrm{al}^{6}$ & $66 / \mathrm{M}$ & Lateral & None & 15 & None & Absent & Absent & Meningothelial \\
\hline 8 & Pushker et al ${ }^{7}$ & $30 / F$ & Superior & $\begin{array}{l}\text { Repeat } \\
\text { orbitotomy }\end{array}$ & 18 & None & - & - & Meningothelial \\
\hline 9 & Pushker et $\mathrm{al}^{7}$ & $40 / M$ & Superomedial & $\begin{array}{l}\text { Repeat } \\
\text { orbitotomy }\end{array}$ & 24 & None & - & - & Meningothelial \\
\hline 10 & Pushker et al ${ }^{7}$ & $9 / \mathrm{M}$ & Superomedial & None & 3 & None & - & Present & Meningothelial \\
\hline 11 & Gündüz ${ }^{8}$ & $56 / F$ & Superior & EBRT & 74 & $\begin{array}{l}\text { Radiation } \\
\text { retinopathy }\end{array}$ & Absent & Present & Meningothelial \\
\hline 12 & Gündüz ${ }^{8}$ & $27 / M$ & Lateral & EBRT & 24 & None & Absent & Present & Meningothelial \\
\hline 13 & Tendler et $\mathrm{al}^{9}$ & $9 / F$ & Medial & $\begin{array}{l}\text { Debulking, proton } \\
\text { beam therapy }\end{array}$ & 12 & None & Absent & Absent & Fibroblastic \\
\hline 14 & Verma et $\mathrm{al}^{10}$ & $16 / F$ & $\begin{array}{l}\text { Superior, } \\
\text { superolateral }\end{array}$ & None & - & None & - & - & - \\
\hline 15 & Gupta (this report) & $70 / F$ & Inferomedial & None & 12 & None & Absent & Absent & Meningothelial \\
\hline
\end{tabular}

nidus for the development of the meningioma. ${ }^{1,4}$ Another hypothesis suggests that sinus enlargement that is found in some patients may displace meningeal cells causing the formation of an ectopic lesion. ${ }^{2}$ However, whether the sinus enlargement is the cause or the consequence of the mass is not yet clear. Most cases are amenable to surgical resection. Recurrence occurred in three cases that were treated with second orbitotomy ${ }^{7}$ or proton beam therapy. ${ }^{9}$ Four cases of residual tumors were treated with craniotomy/external ethmoidectomy ${ }^{2}$ or external beam radiotherapy (EBRT).$^{10}$ Our patient is probably the oldest person (70 years) ever reported to have an ectopic orbital meningioma. She had history of trauma 18 months back, which is probably the etiological factor in development of the mass. The mass was present inferonasally in the anterior part of the orbit, which has not been described before. The case report by Yokoyama et $\mathrm{al}^{5}$ describes ectopic meningioma that presented in the posterior part of the orbit and was very close to the optic nerve. In the present case, the mass presented in the anterior orbit and away from the optic nerve. It was well defined; no evidence of calcification or hyperostosis was seen. Histopathologically, it was of meningoepithelial variant. Patient remained disease free for 12 months after surgical resection.

\section{CONCLUSION}

To summarize, ectopic orbital meningiomas are extremely uncommon. All earlier reported cases were located near the medial orbital wall and one in lacrimal gland region and presented mostly in males. This case of ectopic orbital meningioma is not only in eldest patient ever reported, but also represents the only tumor located inferiorly after only 18 months of head trauma in a female patient in the orbit. Its location away from the optic nerve suggests an origin from ectopic arachnoidal cells promoted by trauma to the head. Ectopic orbital meningiomas are rare tumors, possibly originating from ectopic arachnoid rests, predominantly in males. They commonly involve superomedial part of orbital favorable prognosis, if early diagnosed and excised completely.

\section{CLINICAL SIGNIFICANCE}

Ectopic orbital meningioma should be included in differential diagnosis of anteroinferior orbital mass presenting in elderly patients.

\section{REFERENCES}

1. Farah SE, Konrad H, Huang DT, Geist CE. Ectopic orbital meningioma: a case report and review. Ophthal Plast Reconstr Surg 1999 Nov;15(6):463-466.

2. Johnson TE, Weatherhead RG, Nasr AM, Siqueira EB. Ectopic (extradural) meningioma of the orbit: a report of two cases in children. J Pediatr Ophthalmol Strabismus 1993 Jan-Feb;30(1): 43-47.

3. Spraul CW, Gareis O, Lang GK. Primary extradural meningioma of the orbits: a report of a patient and review of the literature. Klin Monbl Augenheilkd 1996 Nov;209(5):322-327.

4. Arai H, Sato K, Matsumoto T. Free-lying ectopic meningioma within the orbit. Br J Neurosurg 1997 Dec;11(6):560-563.

5. Yokoyama T, Nishizawa S, Sugiyama K, Yokota N, Ohta S, Uemura K, Hinokuma K, Inenaga C. Primary intraorbital ectopic meningioma. Skull Base Surg 1999;9(1):47-50. 
6. Decock CE, Kataria S, Breusegem CM, Van Den Broecke CM, Claerhout IJ. Ectopic meningioma anterior to the lacrimal gland fossa. Ophthal Plast Reconstr Surg 2009 Jan-Feb;25(1):57-59.

7. Pushker N, Shrey D, Kashyap S, Sen S, Khurana S, Sharma S. Ectopic meningioma of the orbit. Int Ophthalmol 2013 Dec; 33(6):707-710.

8. Gündüz K, Kurt RA, Erden E. Ectopic orbital meningioma: report of two cases and literature review. Surv Ophthalmol 2014 Nov-Dec;59(6):643-648.
9. Tendler I, Belinsky I, Abramson DH, Marr BP. Primary extradural ectopic orbital meningioma. Ophthal Plast Reconstr Surg 2015 Oct [Epub ahead of print].

10. Verma SK, Satyarthee G, Borkar SA, Singh M, Sharma BS. Orbital roof intradiploic meningioma in a 16-year-old girl. J Pediatr Neurosci 2015 Jan-Mar 10(1):51-54.

11. Tan KK, Lim AS. Primary extradural intra-orbital meningioma in a Chinese girl. Br J Ophthalmol 1965 Jul;49(7): 377-380. 